\title{
Kitchen chemistry course for chemistry education students: influences on chemistry teaching and teacher education - a multiple case study
}

\author{
${ }^{1}$ University of Jyväskylä, Chemistry, Jyväskylä, Finland, E-mail: piia.nuora@jyu.fi. https://orcid.org/0000-0002-2639-1201, \\ https://orcid.org/0000-0003-1998-9907.
}

\begin{abstract}
:
This study introduces the Kitchen Chemistry $(K C)$ course and its influences on chemistry education as a whole. $\mathrm{KC}$ is considered to be a life-relevant learning environment that engages learners in science through the pursuit of personally relevant and meaningful goals. $\mathrm{KC}$, as a form of interdisciplinary learning, aims to develop boundary-crossing skills and to support the development of pupils' scientific thinking. The purpose of this research was to determine how $\mathrm{KC}$ as a context-based teaching approach applies to chemistry education and what it offers to chemistry teaching and teacher education. We found that $\mathrm{KC}$ gave lower secondary school pupils the opportunity to understand the chemical phenomena in a familiar context. Teachers of visiting groups saw that integration is the challenge: pupils often see the subjects of chemistry and home economics as separate entities. The chemistry education students highlighted real-world connections to chemistry concepts and contexts. They also found $\mathrm{KC}$ to be an interesting form of teaching chemistry. According to the KC course teachers, the students were motivated and excited, and provided positive feedback on the course. These findings suggest that teachers and teacher education students need to be guided in actively using integration.
\end{abstract}

Keywords: context-based education, interdisciplinary learning, kitchen chemistry, life-relevant learning DOI: $10.1515 /$ cti-2018-0021

\section{Introduction}

The phenomenon-based approach is part of the new core curriculum for basic education in Finland (Finnish National Board of Education (FNBE), 2016; Symeonidis \& Schwarz, 2016). The Finnish National Core Curriculum recommends that learning environments offer the means to explore phenomena from different perspectives (Finnish National Board of Education (FNBE), 2016). At the core of phenomenon-based learning are real phenomena that are dealt with in a genuine context. The starting point for teaching is that phenomena or themes of the real world are examined as wholes in each subject and in interdisciplinary studies. Integrative instruction is also an important part of a modern school culture and supports comprehensive basic education. The purpose of integrative instruction is to help pupils see the interdependencies and relationships between the phenomena to be studied (Finnish National Board of Education (FNBE), 2016).

Therefore, in this empirical research we wanted to investigate the kitchen chemistry $(\mathrm{KC})$ context in chemistry education. KC is a life-relevant context and it offers possibilities for interdisciplinarity by combining chemistry and home economics. For this reason, we viewed $\mathrm{KC}$ in school education and chemistry teacher education as a valuable area of study. This research may contribute to how to advance KC in a school context in different grade levels in future.

This article is focused on lower secondary (age group 10-14) level of education and chemistry major and minor students at university.

\section{Defining interdisciplinary learning}

According to Woods (2007), teaching and learning that crosses subject boundaries is a growing theme in higher education (HE) literature in different national contexts. Interdisciplinary thinking can be defined as a capacity to 
integrate knowledge of two or more disciplines (Ivanitskaya, Clark, Montgomery, \& Primeau, 2002). According to Ivanitskaya et al. (2002), interdisciplinary learning "is characterized by the integration of multidisciplinary knowledge across a central program theme or focus" (p. 95). Ivanitskaya et al. (2002) also present Rowntree's (1982) definition of an interdisciplinary approach as "one in which two or more disciplines are brought together, preferably in such a way that the disciplines interact with one another and have some effect on one another's perspectives" (p. 135). Integration or synthesis of knowledge is seen as the defining characteristic of interdisciplinarity and the ability to integrate or synthesize is a beneficial learning outcome of interdisciplinary HE. Thus, the learning outcome is called either interdisciplinary thinking or interdisciplinary understanding. However, interdisciplinary thinking does not occur by itself. It is important that teachers help students to synthesize two or more disciplines (Spelt, Biemans, Tobi, Luning, and Mulder 2009). Ivanitskaya et al. (2002, p. 97) also introduce the concept of multidisciplinary learning that Shafritz, Koeppe, and Soper used in 1988: the concept "refers to the involvement of several different professional areas, though not necessarily in an integrated manner." For the purposes of this article, we will use the most common term, interdisciplinary, to refer collectively to activities that may be multidisciplinary or interdisciplinary.

\section{Context-based chemistry education}

A context provides a coherent structural meaning for something new that can be situated within a broader perspective. These descriptions are consistent with context-based chemistry education (CBCE): chemistry should become more meaningful to students, students should experience their learning as relevant to some aspect of their daily lives, and they should be able to construct logical mental maps of the subject. (Gilbert, 2006) Ültay and Çalık (2012) explain that CBCE aims at making connections between the scientific content of chemistry courses and real life. It also tries to make the learning of chemistry meaningful for students (King, 2012; Vos, 2010, p. 15). CBCE aims to focus on how knowledge is constructed in the scientific discipline of chemistry by letting the students experience 'doing' chemistry. Students need to develop a coherent use of chemistry's specific language (Vos, 2010, p. 15). The original idea of context-based science education was to involve the contexts in which concepts were used and the relations between those concepts in a more explicit way because this would make the subject matter more meaningful for students (Gilbert, Bulte, \& Pilot, 2011).

Yet teaching science through contexts is not sufficient if we want learners to develop their science understanding to solve problems in their everyday life (Campbell \& Lubben, 2000). For example, project work would be an answer to this problem because it makes it possible to train learners to select relevant science concepts to address problems. Everyday situations must be seen as starting points and end points for science education. There must be a meaningful, two-way flow of understanding and knowledge between school science and everyday life experiences. This is a key to a science education that has a personally meaningful impact on the lives of many pupils.

\section{The benefits of kitchen chemistry}

Yip et al. (2012) define KC as a life-relevant learning (LRL) environment. They explain that LRL environments engage learners in science through the pursuit of personally relevant and meaningful goals. These environments can be formal or informal learning contexts. The kitchen can be one everyday context that can support science learning. That is why Yip et al. (2012) developed KC as a guided-inquiry LRL program. It allows participants to learn science and engage in scientific practices within the context of cooking. For example, through semi-structured activities and discussions, learners use their science knowledge to develop their own personal investigations into cooking.

It is important to help learners see the relevance of science to their lives, and KC can assist with this. Clegg, Gardner, and Kolodner (2010) have also created an approach to engaging more learners in science. Their afterschool and summer camp cooking and science programs provide opportunities for learners to learn science through cooking. This especially helps learners who may or may not be interested in science. Their goal was to start with learners' interests in cooking and then help them connect cooking to science. This approach makes it possible to engage learners in authentic scientific practices, which in turn has led to scientifically meaningful experiences for their learners. Jacobsen (2011) suggests that using a non-laboratory space at a school, such as a home economics classroom, can make chemistry accessible to all and is better connected to every student's everyday life. 


\section{Research questions}

This study uses the standard of a comparative case study (Yin, 2009). A multiple case study design was chosen because there are multiple units of analysis instead of the single implementation. This case study compares two groups of learners (pupils on a class visit and teacher education students from a university-level KC course) and two groups of teachers (class teachers and the KC course teachers) within the same context.

Our research questions are as follows:

a. How does KC as a context-based learning approach apply to chemistry education?

b. What does KC offer chemistry teaching and teacher education?

A mixed-methods approach including surveys and interviews was used to examine this phenomenon.

\section{Methods}

\section{The KC course}

The KC course is an optional course in advanced studies for chemistry education students in the Department of Chemistry at the University of Jyväskylä. The KC course is a one-semester course and directed to fourthand fifth-year chemistry education students. The course has been offered twice. During this period, it has been developed with the addition of lecture lessons. The aim of the lectures is to provide more guidance through the content of chemistry related specifically to cooking.

In the course, students explore selected chemistry themes associated with food and food preparation (e.g. Bell, 2014). The KC course is 5 ECTS credits and requires active participation in the course's lectures and laboratory works. Figure 1 presents the contents of the KC course.

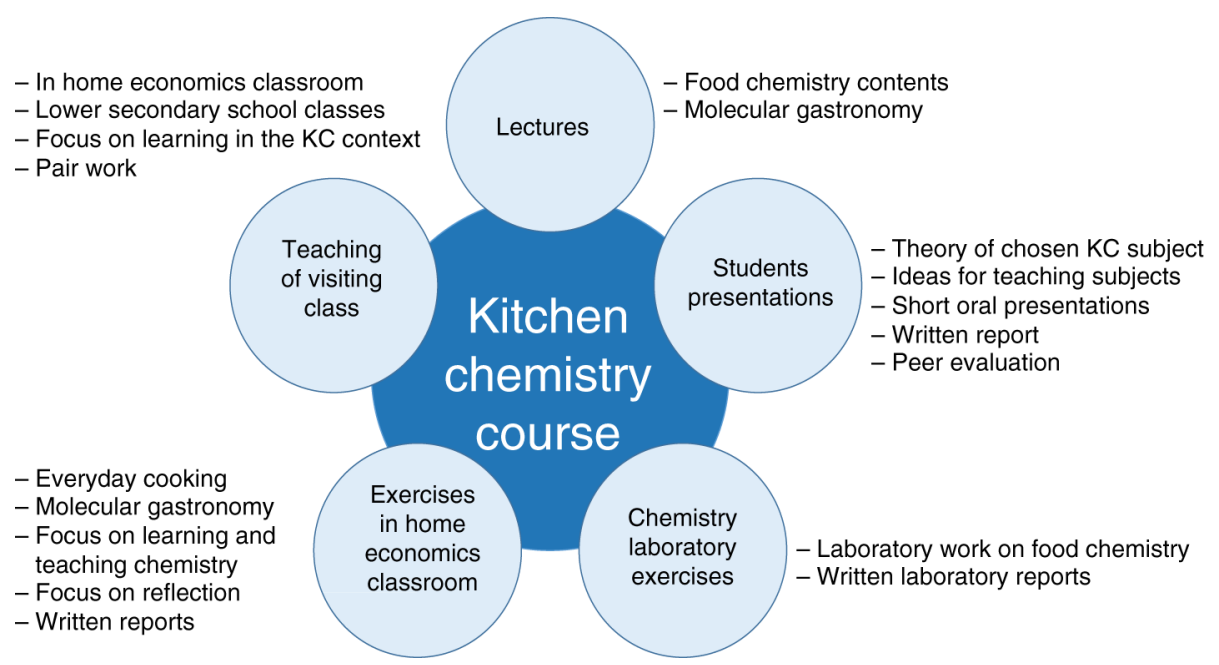

Figure 1: Contents of the KC course.

A representative sample of coursework and contexts are presented in the Table 1 . The course included six 4-h laboratory exercises.

Table 1: KC course activities and contexts.

\begin{tabular}{lll}
\hline Lesson & Title of experimental activities & Context \\
\hline 1 & Spectrophotometric determination of protein concentration in milk samples & Chemistry laboratory \\
& Determination of enzyme activity of potato and sweet potato & \\
& Determination of the amount of milk protein in milk samples using precipitation & \\
& reaction & \\
& Examination of the Maillard reaction in different conditions & \\
& Chemistry of food fats &
\end{tabular}


Liquid nitrogen ice cream

2 MythBusters in the kitchen: myths related to Coca-Cola and bacteria

Rapid protein residue test

Tests for upper secondary school: denaturation of egg white, making thyme, dissolution of potato flour, shortcrust test

3 Taste tests: Basic tastes, verbal description of tastes, Sweetness and temperature, food product taste test

$4 \quad$ KC Menu:

Regular and gluten-free bread rolls

Poached egg and mustard sauce

Blueberry trio

$5 \quad$ KC Menu:

Chemistry laboratory

Home economics

class

Home economics

class

Egg cooked at 68 degrees, fish caviar and bacon blinis with sour cream and caviar Traditional ice cream, made using ice and salt

Lemon sorbet and mango spaghetti

KC Menu:

Home economics

Lamb-filet with ginger and Coca-Cola

class

Mashed potatoes

Stewed red cabbage

Apple pie without apple

Vanilla sauce

\section{Participants and data collection}

Data $(n=75)$ came from four different sources, which are presented in Table 2. The data were collected in spring 2018. The response rate was $100 \%$ for all of the sources.

Table 2: Cases, participants, research methods and the size of the data group.

\begin{tabular}{lllll}
\hline & Case 1: Pupils & $\begin{array}{l}\text { Case 2: Class visit, } \\
\text { teachers }\end{array}$ & $\begin{array}{l}\text { Case 3: KC course, teacher } \\
\text { education students }\end{array}$ & $\begin{array}{l}\text { Case 4: KC course, } \\
\text { teachers }\end{array}$ \\
\hline \multirow{H}{*}{$\begin{array}{l}\text { Method } \\
\text { Data group }\end{array}$} & $\begin{array}{l}\text { Questionnaire } \\
\text { t }\end{array}$ & Questionnaire & Questionnaire & Interview \\
\hline
\end{tabular}

Since we were interested in the KC course as a whole, we selected all the possible groups as cases. All three questionnaires contained questions related to the experience gained from the KC learning context. Items in the questionnaire used a 5-point Likert scale ranging from (1) completely disagree to (5) completely agree, and there were also open questions. The data from the KC course teachers were collected via interviews. Both interviews lasted about $30 \mathrm{~min}$ and were audio-recorded.

\section{Data analysis and research quality}

The quantitative survey data were analyzed for descriptive statistics using SPSS Statistics V24.0. Means, standard deviations and Cronbach's $\alpha$ coefficients were calculated. Cronbach's $\alpha$ indicates scale reliability. The Cronbach's $\alpha$ for case 3 is presented in the next section. The scale displayed good internal consistency.

Content analysis was used to examine the answers to the open questions from the interviews and questionnaires. All learners' and teachers' names are presented in codes. Qualitative interview data were transcribed and coded. The qualitative survey data were also coded.

In the content analysis of the participants' answers to open questions, qualitative interpretations were constructed gradually. First, the participants' answers were processed and analyzed, itemizing the words and concepts they used. After this phase, categories were generated to determine the meanings of concepts. Both authors were involved in the content analysis process. They read the answers, analyzed them independently and discussed the results. The few disagreements that emerged were resolved through discussion and the authors arrived at a consensus (Patton, 2015), which adds to the reliability of the analysis. According to Patton (2015), in a consensus-based theory of truth people can create truth by arriving at a consensus. Example quotations 
from the data are presented to open the analysis to the readers. Different types of research material and the use of multiple coders in the research analysis phase may be seen as a form of triangulation. This study used qualitative as well as quantitative methods of triangulation, thereby contributing to its overall validity (Patton, 2015).

\section{Findings}

\section{Case 1: Lower secondary school pupils}

Background information included gender, class and during what lesson the class visit was carried out. There were 54 pupils: 30 boys and 23 girls. One pupil did not want to share their gender. Thirty-six of the pupils were in Grade 8 and 18 were in Grade 9. Thirty-seven of the pupils were in the elective chemistry course and 17 pupils were in the elective home economics' course. The following codes were used in the content analysis: A, $\mathrm{B}, \mathrm{C}$, and D refer to the group. The numerals $1,2,3$ and so on indicate a specific pupil. The codes are, therefore, $\mathrm{A} 1, \mathrm{~A} 2, \ldots, \mathrm{B} 1, \mathrm{~B} 2, \ldots$, and so on. Frequency refers to the number who referenced the content or a recipe or something else.

Question 1: What was your foremost recollection of working on KC?

a. Content or recipe $(f=25)$

Examples of responses:

B5: Making ice cream from vanilla sauce.

A1: Acids and bases.

b. Working was nice or fun $(\mathrm{f}=7)$

Example responses:

D8: It was nice to cook and see how it is chemistry.

Question 2: What did you learn through KC?

a. Chemistry content $(f=16)$

Example responses:

B15: Chemical phenomena.

b. Cooking skills $(\mathrm{f}=14)$

Example responses:

B16: I learned how to make ice cream.

c. To see the connection between cooking and chemistry $(f=11)$

Example responses:

A6: How chemical phenomena can be found everywhere, especially in the kitchen. Blueberry is really a good indicator.

d. Nothing $(\mathrm{f}=10)$

According to the quantitative data, the pupils liked experimental work in chemistry lessons $(M=4.04, \mathrm{SD}=1.07$, $n=53)$ and they liked $\mathrm{KC}(M=3.93, \mathrm{SD}=1.01, n=54)$. KC helped pupils to see the connection between chemistry and everyday life $(M=3.92, \mathrm{SD}=0.88, n=52)$, but $K C$ had only a minor effect on motivating them to study more chemistry $(M=3.38, \mathrm{SD}=1.03, n=52)$. Although $\mathrm{KC}$ did not have a great impact on their motivation, the majority of the pupils $(n=38)$ would be happy to continue with KC. Four pupils mentioned that they would like to learn chemistry in a chemistry class and home economics in a home economics class. The findings revealed that KC was a new context-based learning environment for pupils.

\section{Case 2: Lower secondary school teachers}

Four teachers of the visiting groups evaluated the teaching of the KC class visit with open questions as well as scale statements. Teachers were asked to answer to following questions: 
Question 1: How would you describe the success of the class visit?

Question 2: What were the challenges for the class visit?

Question 3: How do you evaluate the teaching of teacher education students?

Question 4: Did you get any new ideas for your teaching? What kind of?

Teachers followed the teaching of teacher education students, but did not act as teachers themselves. In citations the following codes are used: Teacher A, Teacher B, and so on.

Teachers felt that the chemistry teacher education students provided clear, well-structured and interesting instruction. However, the scope of the teaching resulted in a rushed atmosphere and the learning environment somehow restricted the teaching. Yet the teachers believed the KC class visit inspired pupils because the learning environment was new to them.

Teacher A: They were interested and enthusiastic.

Teacher B: They liked the new perspective.

They also noted that motivating the pupils can be challenging if two different subjects are integrated into teaching.

Teacher C: Motivation challenge. Pupils often view these subjects as separate.

The visit was successful in inspiring all four teachers to diversify their mindset, and it also interested them in integrating different subjects into their own teaching.

\section{Case 3: Teacher education students}

Table 3 presents the results of the answers given by KC course teacher education students to the survey items. The table includes sample items, means, standard deviations and Cronbach's $\alpha$ for each of the sample items.

Table 3: Sample items, means, standard deviations and Cronbach's $\alpha$.

\begin{tabular}{|c|c|c|c|c|}
\hline Sample items & Number of items & Mean & SD & Cronbach's $\alpha$ \\
\hline I have previously taught $\mathrm{KC}$. & 15 & 2.73 & 1.75 & 0.85 \\
\hline I was very motivated to conduct the course. & 15 & 4.40 & 0.83 & 0.69 \\
\hline The contents of the course were interesting. & 15 & 4.73 & 0.46 & 0.72 \\
\hline $\begin{array}{l}\text { The course inspired to learn new about the } \\
\text { KC course's contents. }\end{array}$ & 15 & 4.80 & 0.41 & 0.71 \\
\hline The KC course appeared useful for the future. & 15 & 4.73 & 0.59 & 0.69 \\
\hline $\begin{array}{l}\text { The KC course answered the needs of } \\
\text { working life. }\end{array}$ & 15 & 4.33 & 0.72 & 0.72 \\
\hline $\begin{array}{l}\text { I got enough peer support in the KC course } \\
\text { from other students. }\end{array}$ & 15 & 4.40 & 0.83 & 0.70 \\
\hline $\begin{array}{l}\text { I got enough support from the KC course } \\
\text { teachers. }\end{array}$ & 15 & 4.67 & 0.49 & 0.72 \\
\hline
\end{tabular}

The Cronbach's $\alpha$ coefficient ranged between 0.69 and 0.85 , meaning the scales displayed good internal consistency. The answers to the first claim indicated that $\mathrm{KC}$ was unfamiliar to the teacher education students, $M=2.73$. Yet as the answers to the other items indicate, teacher education students' perceptions were overall positive. Means ranged from 4.33 to 4.80 on a 5-point scale. The attitudes of teacher education students towards participating in the KC course were positive and their attitudes towards the course content $(M=4.73)$ was high. The course inspired them to learn more about $\mathrm{KC}(M=4.80)$, and they considered it useful for their future in the teaching profession. Table 3 shows that the teacher education students received enough peer support and that the course's teachers were also supportive.

The following codes were used in content analysis: $\mathrm{R}$ indicates the respondent and the accompanying numeral (1, 2, 3 etc.) indicates an individual student. The codes therefore follow the patter R1, R2, R3, and so on.

Question 1: What motivated you to participate in the KC course?

a. Learning something new $(\mathrm{f}=14)$ 
Example responses:

R8: For once there was a course that reflects everyday life. I will implement a similar course in upper secondary school.

b. Interesting theme $(\mathrm{f}=11)$

Example responses:

R5: Integrating multiple substances is the future.

c. External factors $(\mathrm{f}=9)$

Example responses:

R9: Interest in cooking, recommendation.

Students felt that the course would be useful in their future work as teachers. They were also interested in the chemistry behind cooking. The KC course was seen as an interesting course that demonstrated the context well.

Question 2: In what ways did the KC course develop your own skills?

a. The course deepened knowledge of chemistry $(\mathrm{f}=16)$

Example responses:

R11: The course opened up chemistry and showed me how to look at cooking from the point of view of chemistry.

b. The course gave new ideas for teaching $(f=7)$

Example responses:

R6: It offered new and wider knowledge and experience in teaching.

c. The course gave opportunities to work in different learning environments $(f=2)$

Example responses:

R3: The course taught me to work in different and more discerning learning environments.

The students found that the KC course helped to deepen their chemistry expertise. The course showed an example of how chemistry is related to cooking. In addition, the experimental work deepened the theory of chemistry. Another important element of the course was that it provided an example of how observations, either in the laboratory or in the kitchen, can be explained to pupils in the teaching of chemistry. In general, the course gave students new ideas for chemistry teaching and they saw ways in which the integration between subjects could be performed. The course also showed the importance of new learning environments: it helped to work in a more accessible learning environment.

Question 3: What challenges did you encounter when designing and implementing class visits?

a. Challenges related to the design phase $(\mathrm{f}=12)$

Example responses:

R4: Difficult to find the theory of topics because they are so complex.

b. Challenges related to the teaching $(f=11)$

Example responses:

R4: A new learning environment. You do not know the pupils. A large group and group of people spread around the class.

c. No challenges $(\mathrm{f}=2)$

In particular, finding a suitable theoretical level for pupils and managing their own theoretical knowledge in the context of $\mathrm{KC}$ created uncertainty at the design stage. Some of the students went on a class visit to a primary school. This was considered a challenging factor because the students lacked experience in teaching pupils of that age group. Teaching-related challenges included the learning environment, the group, and the teaching. The group of pupils was partly too large because there were many variables in the large groups and not everyone was able to receive equal guidance. In addition, there were foreign pupils to teach. This made challenges to the design and teaching phases for teacher education students. 


\section{Case 4: KC course teachers}

Two KC course teachers were also interviewed. Teacher 1 and Teacher 2 have been teaching the course twice. Teacher 1 has helped develop it in its current form. In the first year, Teacher 2 was only responsible for arranging class visits and student guidance during the visits. In the second year, Teacher 2 was also responsible for laboratory work.

The teachers were asked about their approach to teaching the KC course. Teacher 1 viewed the KC course teacher education students as smart and motivated university students who were clearly enthusiastic about the theme. This teacher wanted to offer students a good opportunity to learn.

Course participants included both chemistry majors and those who are minoring in the subject. The chemistry majors clearly possess better and deeper skills in chemistry. Thus, a significant challenge for the course is the heterogeneity of students. Teachers have accounted for this by, for example, forming groups so that chemistry majors and those minoring in it work in pairs in experimental work and during class visits. The course teachers identified time-related and work-related issues as a second challenge. The course is to be completed within 2 months, so organizing the workload in a manageable way is difficult.

The teachers observed clear growth in students' interest during the course. Students gave direct positive feedback on the course. The growth in interest was also seen in the level of performance:

Teacher 1: Everything done in a laboratory or a home economics class, or students working on their written reports and oral presentations - everything is done at an excellent level. And it seems to me that motivation is good!

The course includes the planning and implementation of a class visit. At this stage in their education, teacher education students do not necessarily have an idea of how much time experimental classroom work needs. Sometimes the students need to be told that their plan needs to be reconsidered. Even if the course teachers would themselves arrive at solutions for the plans in some situations, they want to give students the opportunity to work differently if their way is just as viable.

The main goals of the $\mathrm{KC}$ course are to bring context-based learning into teaching and to give students the opportunity to develop through the challenges in this style of learning integration. Such an approach, however, represents a significant change when students leave their core competence area and move, for example, from the chemistry class to the home economics class. The course encourages students to explore outside of their comfort zone and to cooperate with teachers of different subjects.

To develop the course, the teachers should increase the number of lectures with guided teacher-led instruction in the natural sciences content. In addition, it would be good to think about what topics are being examined, even though certain reactions and phenomena are repeated from year to year. Teachers feel that experimental work is mostly functional and only minor changes need to be made to the course content for the next time.

\section{Conclusions and implications}

Science and scientific practices can be studied in the context of cooking. Pupils make observations by cooking, they discuss chemistry based on their own observations and in this way learn the chemistry context behind recipes. It is important to help learners see the relevance of science to their lives and engage them in chemistry. When pupils are able to see how laboratory work relates to their real life, they are likely to be more motivated in the area of science they are investigating. The KC context provides coherent structural meaning for cooking that can be situated within a chemistry education (e.g. Gilbert, 2006). For example, according to Cheung (2009) chemistry learning should be connected to the world outside of school to develop students' ability to use chemistry skills and knowledge in real-world settings. This also makes learning more motivating for students.

In their study, Sevian, Dori, and Parchmann (2018) call for further research to understand how to identify and improve contexts that both interest students and increase their cognitive activity. Our research is responding to this call. Our results suggest that $\mathrm{KC}$ was an interesting and motivating theme for all of the participants. It integrates the knowledge of two disciplines, chemistry and home economics, and is a form of interdisciplinary teaching (e.g. Ivanitskaya et al., 2002). A clear connection to students' everyday life in the course was identified, which is useful for teachers when they are attempting to connect chemistry with students' personal lives (de Jong, 2008).

Some pupils reacted negatively to the integration of chemistry and home economics. Combining two subjects is difficult for pupils and this can negatively affect their motivation to further study, for example, KC. Bradbeer (1999) sees the following problems in achieving interdisciplinarity in student learning: (1) problems in working across disciplines, (2) problems of working in different disciplines, and (3) problems in synthesizing different disciplines. These problems suggest, in part, that we need more practice with integrating disciplines. 
New learning methods can be taught to learners, and a unique learning situation enables a new learning experience, where knowledge is based on a change in experience (Kolb \& Boyatzis, 2001, p. 227; Kolb \& Kolb, 2005). KC offered teacher education students' a deeper knowledge of chemistry by providing such an environment. The course shows a pattern: students leave their comfort zone and cooperate with the teachers of different subjects. The teacher education students were enthusiastic, and felt positively about the context as well as motivated to learn new things. The KC course included lots of discussion and reflection during laboratory work and the home economics class sessions. Students used written reports to reflect on the themes studied. They applied knowledge in a new context and situation, experience that will help them in their future work as teachers. So, one result of the KC course is that students developed professionally. Challenging aspects of the course included time and workload.

The two KC course teachers were enthusiastic about teaching the subject, and they wanted to offer students the best possible opportunity to learn. The teachers were surprised at how much direct positive feedback they received from the course's students. The course teachers saw the heterogeneity of students as the main challenge of the course.

Overall, the findings of the present study suggest that teachers and teacher education students need to be guided to actively use integration. Students often have a problem with working in and across different disciplines (Spelt et al., 2009). Teachers, therefore, have to help students synthesize a range of disciplines because interdisciplinary thinking does not occur by itself. This is why we wanted to include the KC course in chemistry teacher education. The KC course creates a challenging integrative context for chemistry teacher education, and it offers novel possibilities to teach chemistry in a new learning environment, one that goes beyond the chemistry laboratory.

\section{Acknowledgements}

We are extremely grateful to all the pupils, chemistry teacher education students and teachers who participated in this study.

Disclosure statement: No potential conflict of interest was reported by the authors.

\section{References}

Bell, P. (2014). Design of a food chemistry-themed course for nonscience majors. Journal of Chemical Education, 91(10), 1631-1636. doi:10.1021/ed4003404.

Bradbeer, J. (1999). Barriers to interdisciplinarity: Disciplinary discourses and student learning. Journal ofCeography in Higher Education, 23(3), 381-396.

Campbell, B., \& Lubben, F. (2000). Learning science through contexts: Helping pupils make sense of everyday situations. International Journal of Science Education, 22(3), 239-252. doi: 10.1080/095006900289859.

Cheung, D. (2009). Students' attitudes toward chemistry lessons: The interaction effect between grade level and gender. Research in Science Education, 39(1), 75-91.

Clegg, T. L., Gardner, C., \& Kolodner, J. L. (2010). Playing with food: Moving from interests and goals into scientifically meaningful experiences. In Proceedings of the Ninth International Conference of the Learning Sciences (ICLS) (Vol. 1, pp. 1135-1142).

de Jong, O. (2008). Context-based chemical education: How to improve it? Chemical Education International, 8(1), 1-7. Retrieved from http://old.iupac.org/publications/cei/vol8/index.html.

Finnish National Board of Education (FNBE). (2016). National core curriculum for basic education. Helsinki: Finnish National Board of Education.

Cilbert, J. K. (2006). On the nature of "context" in chemical education. International Journal of Science Education, 28(9), 957-976. doi:10.1080/09500690600702470.

Gilbert, J. K., Bulte, A. M. W., \& Pilot, A. (2011). Concept development and transfer in context-based science education. International Journal of Science Education, 33(6), 817-837. doi:10.1080/09500693.2010.493185.

Ivanitskaya, L., Clark, D., Montgomery, G., \& Primeau, R. (2002). Interdisciplinary learning: Process and outcomes. Innovative Higher Education, 27(2), 95-111.

Jacobsen, E. K. (2011). Kitchen chemistry. Journal of Chemical Education, 88(8), 1018-1019. doi:10.1021/ed200359x.

King, D. (2012). New perspectives on context-based teaching: Using a dialectical sociocultural approach to view teaching and learning. Studies in Science Education, 48(1), 51-87. doi:10.1080/03057267.2012.655037.

Kolb, D. A., \& Boyatzis, R. E. (2001). Experimental learning theory: Previous research and new directions. In R. J. Sternberg \& L.-F. Zhang (eds.), Perspectives on thinking, learning, and cognitive styles (pp. 227-247). Routledge.

Kolb, A. Y., \& Kolb, D. A. (2005). Learning styles and learning in higher education. Academy of Management Learning \& Education, 4(2), 193-212. Patton, M. Q. (2015). Qualitative research \& evaluation methods (4th ed.). United Kingdom: SAGE Publications. 
Sevian, H., Dori, Y. J., \& Parchmann, I. (2018). How does STEM context-based learning work: what we know and what we still do not know. International Journal of Science Education, 40(10), 1095-1107. doi:10.1080/09500693.2018.1470346.

Spelt, E. J. H., Biemans, H. J. A., Tobi, H., Luning, P. A., \& Mulder, M. (2009). Teaching and learning in interdisciplinary higher education: A systematic review. Educational Psychology Review, 21, 365-378. doi:10.1007/s10648-009-9113-z.

Symeonidis, V., \& Schwarz, J. F. (2016). Phenomenon-based teaching and learning through the pedagogical lenses of phenomenology: The recent curriculum reform in Finland. Forum Oświatowe, 28(2), 31-47. Retrieved from http://forumoswiatowe.pl/index.php/czasopismo/article/view/458.

Ültay, N., \& Çalık, M. (2012). A thematic review of studies into the effectiveness of context-based chemistry curricula. Journal of Science Education and Technology, 21(6), 686-701.

Vos, M. A. J. (2010). Interaction between teachers and teaching materials: On the implementation of context-based chemistry education. Eindhoven: Technische Universiteit Eindhoven. doi:10.6100/IR684861.

Woods, C. (2007). Researching and developing interdisciplinary teaching: Towards a conceptual framework for classroom communication. HigherEducation, 54(6), 853-866.

Yin, R. K. (2009). Case study research-Design and methods (4th ed.). Applied social research methods series (Vol. 5). Thousands Oaks, CA: Sage.

Yip, C., Clegg, T., Bonsignore, E., Lewittes, B., Guha, M. L., \& Druin, A. (2012). Kitchen chemistry: Supporting learners' decisions in science. Paper presented at the ICLS International Conference of the Learning Sciences. Sydney, Australia. 